\title{
METAPHOR AS A BASIC MECHANISM OF ART (PAINTING)
}

\author{
Viktor F. Petrenko, \\ Lomonosov Moscow State University \\ Moscow, Russia \\ Evgeniya A. Korotchenko \\ Psychological Institute of Russian Academy of Education \\ Moscow, Russia
}

This article describes research on visual semantics, different forms of metaphor used in rhetoric and philology (tropes: metonymy, hyperbole, litotes, oxymoron, and others), and images, which are metaphorical also. The research was carried out using paintings. The authors state that the function of metaphor is to transform the sense of the image from a psychological point of view.

Keywords: visual semantics, sense, tropes, metaphor, metonymy, hyperbole, litotes, oxymoron, image, mental energy.

Despite the fact that literature (the muse of epic poetry, Calliope) and painting art (the god Apollo) are traditionally considered two different types of art, distinctions among an image, a concept, and a word are rather conventional. Artists do not make a copy of their own perceptions, but, according to Leont'ev (1997, p. 287), they set themselves the task of realizing the existence of human objective reality and its position in the universe.

Concepts (secondary images; see Gostev, 1998) - that is, images of fantasy or memory - appear in a person's mind by means of imagination and have no physical stimulus. The transitional position from image to concept is ill-studied in the psychology of perception. This field of psychology is almost unknown, but the heuristic approach used in its research is based on holographic models of consciousness and memory.

The concept, a virtual and invisible material, makes an artist create on a canvas. Just as a musician composes music using the "mute" piano, so an artist paints a picture without using brushes, but in his or her own mind. 
Even if artists create their paintings in the open air, they do not copy reality but seek harmony between their thoughts and their emotional state. Scenery is a reflection of the artist's mind (see Petrenko \& Korotchenko, 2008). Both consciousness and imagination run through the works of both writers and artists. "Art is creative thinking, in other words, it is thinking through images" (Potebnya, 1990, p. 163).

Discussions of issues regarding the image in art are found in Arnheim (1973, 1974, 1994, 2004), Basin, Prangishvili, \& Sherozia (1978), Mol' (1966), Petrenko (1988, 1997, 2005), Rappoport (1978), Ruuber (1985), Yarbus (1965), Zinchenko (2001, 2005), Znakov (2005).

An artist is as reflective as a writer who creates narratives or a philosopher who uses general categories. If an artist starts from consciousness of the plot and determination of the semantics and then goes for an immediate creation on a canvas, a spectator gets the artist's semantics and plot, gets a perception of the visual pictorial idea.

A spectator's perception of paintings requires mutual action just as a writer's words require correction and comprehension of the text's plot by readers (see Leont'ev, 1997; Ushakova, 2006). On looking at a canvas covered with watercolors (in Ferdinand de Saussure's terms, a plan of expression), a viewer comprehends the plot and the spirit of the creator; the visual perception of color patterns helps the viewer realize the concepts that the artist had in mind.

In his lectures on general psychology, A. Luria used to tell his students about the simultaneousness of the image and the successiveness of speech (text), seeing them as basic contrasts (Luria, 2004). But here, in our opinion, the distinction between an image and a text is not absolute. Melchuk (1974) developed a model for formalizing the meaning of the text; this model compares the content, a sequence of the text, to the "image", to the simultaneous connected and oriented semantic graph that has the basic meanings (the words of the language) and the generalized relations (the predicates of the language). The simultaneous language of meaning, in our opinion, is extremely promising in psychology, where it could be used to study holistic insight reproductions of gestalts in Dunker-type mental tasks.

The use of the analogy of an image and a text allowed us to define "the image as a perceptive statement about the world" (Petrenko, 1976, p. 270) and makes it possible to use the methods of psychosemantics and linguistics in the analysis of visual art (see Petrenko, 1998, 2005). 


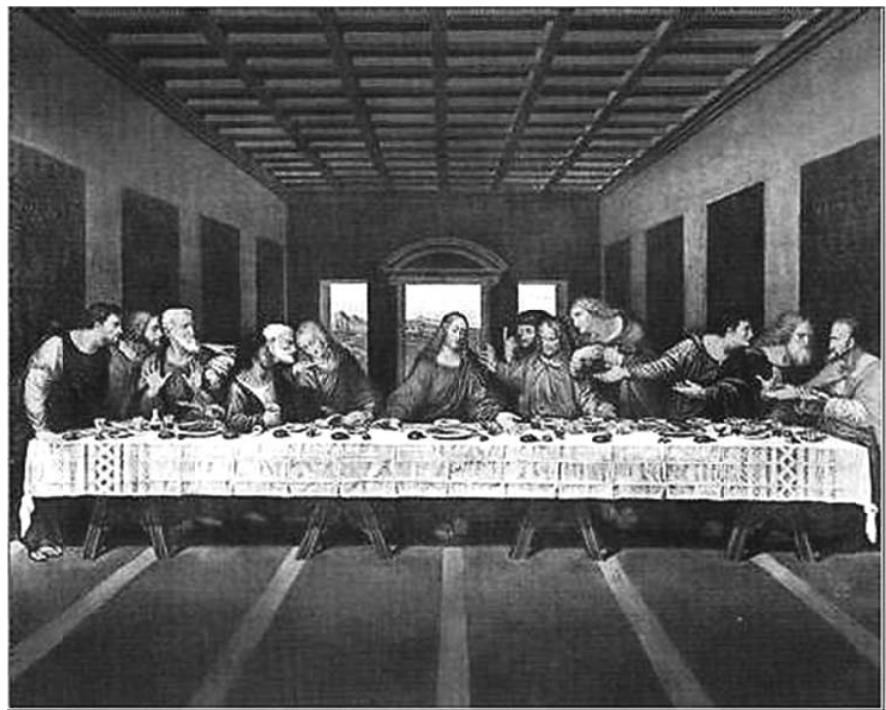

Picture 1. Leonardo da Vinci, The Lord's Supper

Paintings, as a rule, have a literary subject, simply represented in the title, which provides the literary discourse, the direction for associations. This is true primarily about classical painting, which tends to have development, but development beyond the art work. "[A] literary subject necessarily takes us beyond the picture, requires development" (Ingarden, 1962, p. 281). To understand what is depicted in the painting, it is necessary to refer to its literary aspect (to its literary subject).

According to Ingarden (1962, p. 283):

If we leave aside the whole legend of Jesus and turn it off in our minds while looking at the picture [Picture 1], the picture... will probably be something entirely different from what it should represent in relation to its title. We would not see Jesus and his disciples gathered for a last meal and would not relate the eating of bread and the drinking of wine to Christian doctrine, but we would see just a group of men of different ages around the table and would not or would hardly understand their gestures and facial expressions. But even though the picture would contain a specific literary 
topic, although quite different from what is expressed in it, when we know the story about the Jesus, the name of the picture draws our attention to a specific point in history.

An artistic image is symbolic by nature. "The artistic image, devoid of a generalizing character and a powerful symbolic picture of this life, is always only a weak naturalistic copy of life" (Losev, 1991, p. 251).

The transition from an image to a symbol, according to Bakhtin, "makes it semanically deep and gives a semantic perspective. ...The original symbol is compared with the idea of the global totality by content, having space and the human universe" (Bakhtin, 1986, pp. 381-382).

Understanding the symbolic meaning of a work of art, according to Arnheim (1994), is the main task of a viewer who looks at a picture. Contemplating the work, the viewer is experiencing the atmosphere depicted in the painting: a misty river arouses feelings of neglect and sedation, a mountain arouses the feeling of grandeur. Each work of art or visual symbol used in the genre of landscape has its own interpretation and is associated with its own meaning (see Petrenko \& Korotchenko, 2008). For example, peacefulness can be depicted as a serene sea and a bright sky, but it can hardly be depicted as a crowd of people in an urban context.

As an element of art language, the artistic image in each work of art is unique. The artistic symbol is multidimensional: it arouses various feelings and not just serenity. It can give a feeling of cool detachment and sadness, and it can create a sensation of time dilation or other feelings; the symbol can correlate the viewer's state with his or her thinking. Complex emotional responses of the viewer to a work of art are the result of the successful use of the means of expression, particularly tropes, which serve to create an artistic image.

One of the definitions of tropes was given in ancient times by the great Roman orator Quintilian: "A trope is a change of the meaning of a word into another one, enriching its semantics" (quoted in the Yartseva, 1990, p. 520). In the theory of rhetoric there is another definition of tropes, according to which a trope (from the Greek tropos) is "a word or a phrase in a figurative meaning, a figurative expression, a shift in the semantics of a word from the direct meaning to the figurative, such as metaphor, metonymy, allegory, litotes, hyperbole" (Alexandrov, 1999, p. 45). Most trope constructions are based on "a semantic incompatibility. Creating a 'semantic paradox situation', tropes make the boundaries 
between the possible and the impossible in a language, providing the conditions to get into the deep structure of reality (Naer, 1976, p. 77).

\section{Metaphor}

Metaphor is traditionally defined as a type of trope, a transmission of the properties of one object (or phenomenon or aspect of life) to another because of their similarity in any aspect or by contrast (in Greek, metaphora is a figurative meaning). Examples of metaphors: fatal fire of life (Alexander Blok); Russia - a kiss in the cold (Velimir Khlebnikov) (quoted in Zaretskaya, 2002, p. 261). A number of authors - for example, Timofeev and Turaev (1978), Zaretskaya (2002) - define metaphor as a hidden comparison in which the words like and as if are omitted but implied. Metaphor is remarkable for its conciseness and reticence; thus, it activates the reader's perception. Unlike comparison, in which both of the objects that are being compared remain independent - even though the degree of independence differs (Chernets, 2000a) - metaphor creates a single image - in other words, it reduces the difference between objects or concepts (Chernets, 2000b). "In relation to metaphor such methods of expression as allegory, personification, synesthesia can be regarded as its variations (Arutyunova, 1979, p. 130).

From the perspective of psychology, the words that constitute a metaphorical pair are connotative (semantic) synonyms - for example, in the well-known poem by Mikhail Lermontov:

Clouds in the sky are eternal wanderers

Along the sky-blue steppe like a chain of pearl

Rushing like me, the exiled

From dear North to southward.

By means of Charles Osgood's semantic differential we analyzed (by scale model) the image of the "clouds" and the image of "the exiled," and even though these concepts belong to completely different conceptual classes (in the space of the semantic differential by a number of basic factors), they have similar positions (which means they are connotative synonyms).

Indeed, what do a traveler and clouds have in common? According to the archaic anthropomorphism of inanimate objects ("the wind blows," "the rain pours," "the cloud runs"), we can give the elements of a meta- 
phorical pair similar psychological sensations, and, having established their identity by a number of factors, we can make transmit the properties of one object to the other. For example, having set the similarity between "clouds" and "a traveler" according to the quality of loneliness, we define both of them as being rejected.

On the basis of metaphoric expression mythological thinking is possible. So, in the 1990s, in the discussions about the possibility of the private ownership of land, the following argument was used: Our land feeds us, it gives us life, it is our mother, and a mother may not be sold. So, from connotation synonymy (one of the common meanings: life creation) the quality of one object (the mother) is transmitted to another (land) - in particular, the impossibility of selling property.

Metaphors appear in dreams, poetry, the individual and collective unconscious. Thus, the presence of affect decreases the dimension of semantic space (see Petrenko, 2005), and categorization of objects transmits a large number of highly differentiated subject-denotative characteristics to a limited number of basic underlying connotative factors. The objects belong to different semantic areas in the ordinary state of consciousness and have nothing in common in the object plan; when the semantic space is flattened, the objects become close because of their position in connotative space, and thus they become connotative synonyms and can be used as metaphors.

Metaphor and metonymy are used by a number of well-known researchers in semiotics and cultural studies of visual arts like film (Arutyunova, 1979, 1990; Ivanov, 1973, 1981, 1998; Lotman, 1973; Shklovsky, 1983).

Visual comparisons in which metaphor, metonymy, contrast, and other literary techniques and tropes are used are quite common in medieval and modern paintings. Pictorial metaphor as well as "an artistic image" are concepts that are well known by art critics but are hardly used in psychology. We quote here intuitional descriptions of metaphorical painting from an Internet article dedicated to the anniversary exhibition of works by Dmitry Zhilinsky (Khachaturov, 2002, p. 1):

The angels by Zhilinsky are metaphors. The language of metaphors in secular painting (sacred one does not count, because it is a window, opened from where metaphors become Revelation) is appropriate when the interpretation is optional. This option illustrates the biblical saying "The 
wind blows where it wishes." Here, an example from the distant past is illustrated in the painting Arnolfini Portrait by Jan van Eyck. We see a brilliant portrait. Wow! It makes a heart pound. Sweat comes off on the forehead. And only then, in our mind, do we realize that the usual order is no longer possible, that before us is not the everyday chaos but a cosmic mystery. We take a volume of Erwin Panofsky and eagerly look for confirmation of our guess. We start interpreting hidden emblems and symbols in everyday life. Here is an example from the recent past - the portraits of Valentine Serov. The portraits are gorgeous. However, they do not claim to be Borges's "drop," on which the universe shines and shakes. The hidden metaphors in Serov's works become an ingenious scenic pantomime. There is no more subtle sacral symbolism. But visual associations are successfully found: a - peaches - freshness, the princess - a vase - luxury, and so forth. In the first (van Eyck) and in the second (Serov) paintings a viewer has a choice: either look without "translating" into the metaphorical language or guess and compare.

The construction of a metaphor is supposed to unite dissimilar images, creating poetic expressiveness. "The two points that it (a metaphor) consists of, aesthetically, are quite equal. And this equality makes both points single and undividable" (Losev, 1991, p. 59). "Metaphor does not allow an object to belong to the class which it is actually a part of but tries to make it a part of the category to which it cannot be assigned on a rational basis. Metaphor is a challenge to nature. The source of metaphor is a deliberate error in the taxonomy of objects. Metaphor works as a categorical shift. Metaphor is not a reduced comparison, as it was defined in the time of Aristotle, but reduced contrasting" (Arutyunova, 1990, pp. 17-18).

In contemporary articles it is possible to find several definitions of visual metaphors. Film theorist Carroll (1996) believes that a visual image cannot be considered a metaphor if there is no merger of the two different areas of experience that form a new, spatially limited reality. Metaphor is formed by substituting unexpected visual elements for expected ones (in this case there should not be an existing, conventional connection) (Forceville, 1994, 1995, 1996).

Such definitions clarify the nature of visual metaphors; however, they are private descriptions of visual metaphors. According to Arutyunova (1990, p. 22): 


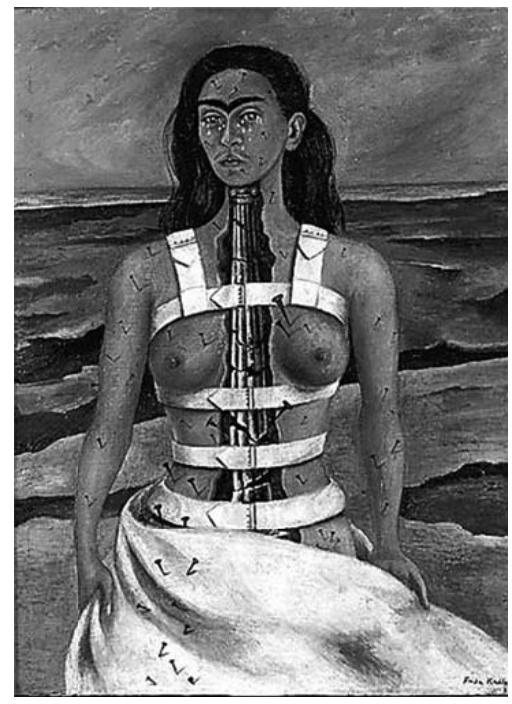

Picture 2. Frida Kahlo, Broken Column

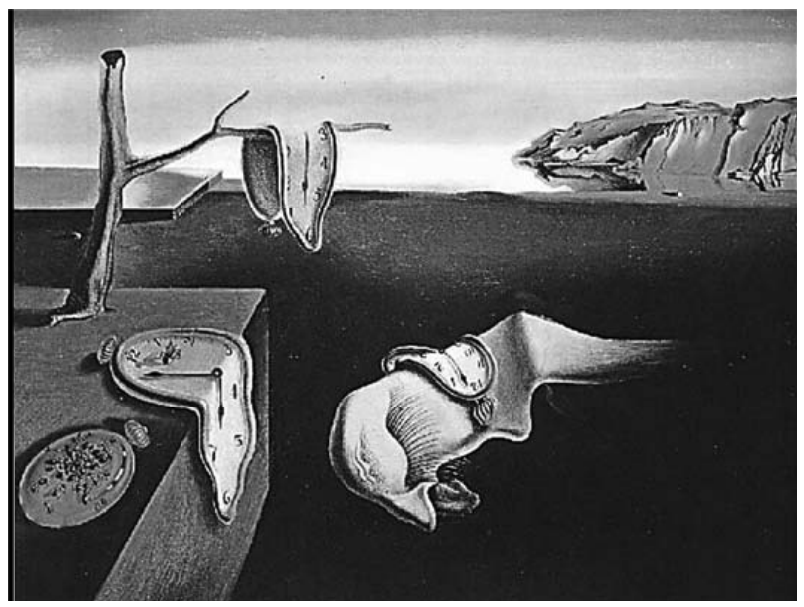

Picture 3. Salvador Dali, The Persistence of Memory 
Graphical metaphor is quite different from verbal metaphor. It creates neither new meanings nor new synonyms; it does not go beyond its context and does not have a stable position in the language of painting or film; it has no prospects for existence beyond the work of art in which it exists. The mechanism of creating pictorial metaphor is entirely different from the mechanism for verbal metaphor, a prerequisite of which is that both its subjects (denotations) belong to different categories: the basic subject (which is characterized by the metaphor) and the auxiliary subject (which implies its direct meaning). Pictorial metaphor lacks a double subject. It is nothing more than an image, which acquires in one or another artistic context a symbolic (key) value, a broader, generalizing meaning.

Metaphor in painting is a source of bright ideas; it creates figurative works. Visual and verbal metaphors should be distinguished on the basis of their different representations - that is, both visual and verbal metaphors are two ways of expressing the same meaning. The meaning and the metaphor in images can also be comprehended if the idea is given verbally (Refaie, 2003). "We read the literary text as a code. ...Character, symbol, metaphor, and allegory indeed have more or less intelligible verbal and semantic meanings" (Arabov, 2003, p. 30). Most verbal metaphors can be extended into a visual plan - that is, they can be depicted in a picture or in a painting. However, it is better (easier) to express actions and chronology verbally, and spatial relationships visually.

Pictures 2, 3, and 4 are examples of visual metaphors. In the selfportrait Broken Column, Frida Kahlo substitutes an ancient column broken in several places for her spine; the pain is depicted as nails covering her body. Kahlo feels like a broken column, which is a metaphor for her feelings or sensations. In visual metaphors the various objects and their properties are often combined in unexpected ways, making new meanings.

A visual metaphor is always a mystery for a viewer. It often combines incongruous attributes of various objects, immediately reversing the usual perception. A verbal metaphor can be reflected in visual terms and can be easily recognized, but a purely artistic visual metaphor is more difficult to recognize.

Salvador Dali's The Persistence of Memory (Picture 3) is a visual metaphor. Generally, we can say that this picture is a metaphor for time flexibility, time relativity; the image of the metal pocket watch next to 


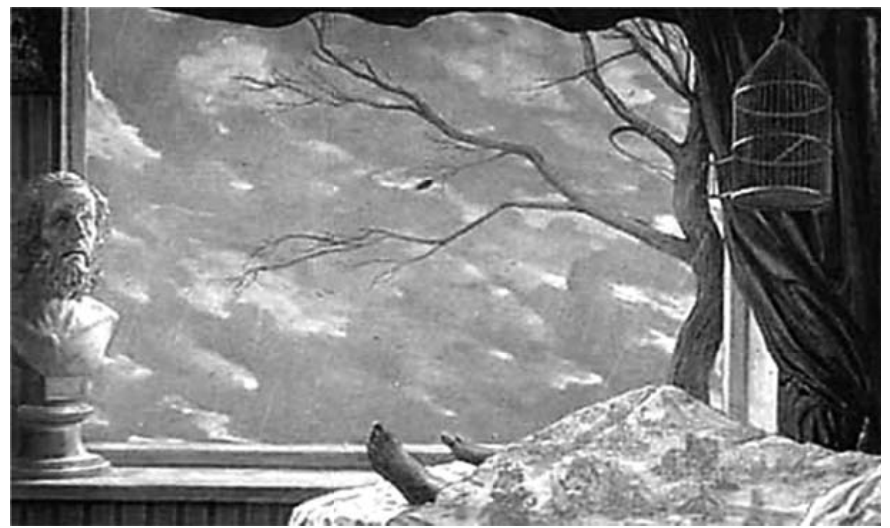

Picture 4. Ilya Glazunov, The Last Leaf

the "soft" one suggests that time may move differently: flowing slowly or speeding sharply.

Another example of visual metaphor is the painting The Last Leaf by Ilya Glazunov (Picture 4). An open cage having no bird inside is a metaphor for the soul escaped from the body. A lone leaf on the tree portrays the moments of life slipping away. The bust standing on the window sill and a sick man create a contrast: life vs. death, eternal vs. temporal. A viewer can see the "autumn" mood in the painting through the clouds, the last leaf on a dry tree, the empty birdcage, the bust: a human life is about to break off as soon as that last leaf falls off the branch. This painting is an example of a visual citation; it illustrates the story The Last Leaf by $\mathrm{O}$. Henry.

Like a literary text, a painting often has interlocking sets of expression. The painting by Glazunov is a good example. In this painting we can see two visual metaphors, a contrast and a synecdoche, creating a complete artistic image.

\section{Other Tropes}

Metonymy (in Greek metonymia, renaming) in its linguistic meaning is a trope based on the principle of contiguity. An object gets the name of another related object. The phenomena, connected through 
metonymy and forming "a subject pair," can be connected in various ways: for example, the object and the material (have not eaten from the silver but from the gold - Alexandr Griboyedov), (All in tulle and panne, Helen entered the room - Alexander Galich); the content and the container (The burnt furnace is crackling - Alexander Pushkin); the property holder and the property (Courage conquers cities); the creation and the creator (A man... will take Belinsky and Gogol from the marketNikolay Nekrasov); the place and the people residing in the place (All of Moscow speaks about it). Metonymy as the transmission of a name is based on the contiguity of meanings, mostly spatial, temporal, and causal. Specifically, in metonymy the object's name exists irrespective of the subject, and they do not make a single object (Zaretskaya, 2002). Metonymy is a bright, symbolic trope. It creates and enhances the visually perceptible representation, describing the phenomenon indirectly. Lotman and the Tartu-Moscow Semiotic School (Ju.M. Lotman i tartusko-moskovskaja semioticheskaja shkola, 1994) define metonymy as a trope that distinguishes substantial and specific aspects and excludes nonessential aspects.

We can see metonymy in the painting The Doll by Glazunov (Picture 5). A doll, not a child, is portrayed in the painting, but the doll reminds the viewer of a child; here is the analogue of metonymy in a picture.

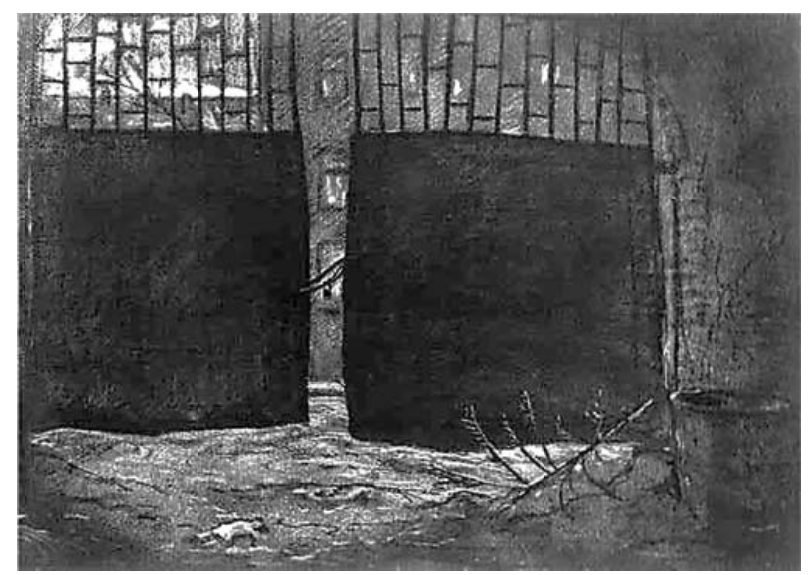

Picture 5. Ilya Glazunov, The Doll 


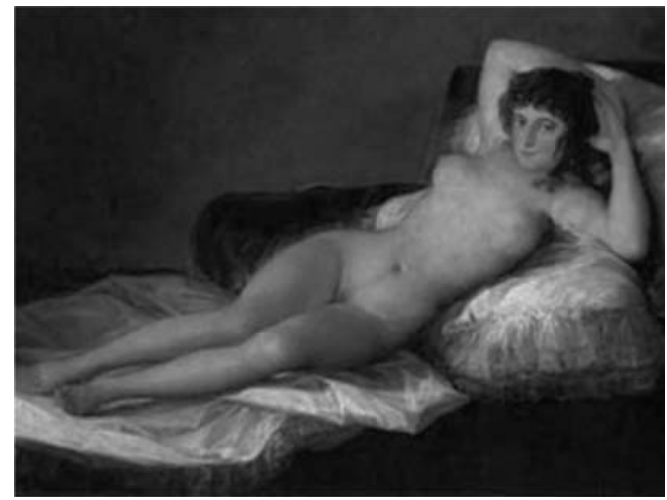

Picture 6a. Francisco Goya, The Naked Maja

Visual metonymy works differently from verbal metonymy: no names are given to objects, only the connection between them remains for example, the child who was playing with the doll. Thus, the image of the doll refers the viewer to a child, denoting a retrospective focus of the story. A viewer seeing the doll visualizes and creates in his or her mind a story (even a most horrific one) about the child who was playing with the doll.

In paintings metonymy may be used as a hidden citation: for example, the French Impressionists often used the plots, themes, paintings of

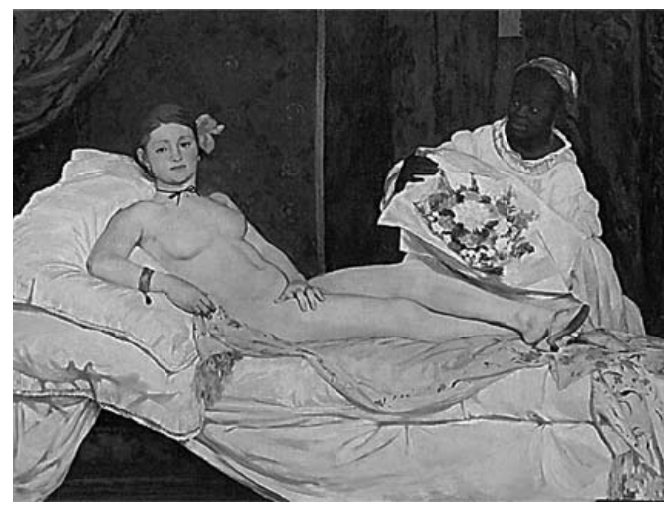

Picture 6b. Edouard Manet, Olympia 


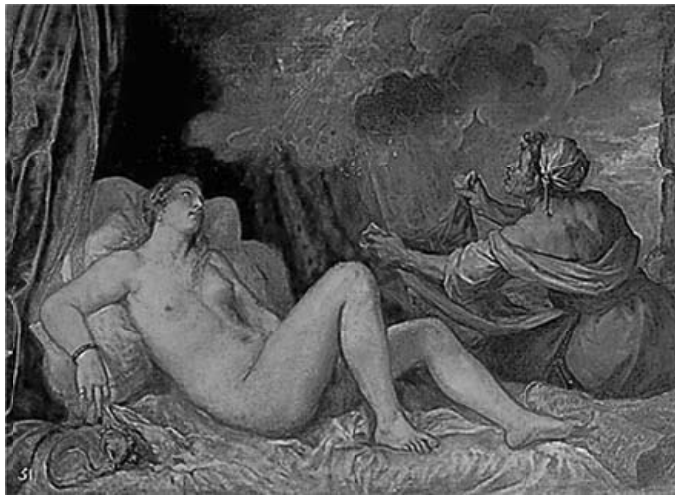

Picture 6c. Titian, Danae

the great Renaissance masters to depict eternal human problems in contemporary time and to give their own work a historical context (although at that time the correlation of the classical images of the great masters with the Impressionists, who eventually also became great, shocked the audience). In the paintings by Francisco Goya (The Naked Maja, Picture 6a) and by Edouard Manet (Olympia, Picture 6b) one can see citations to the famous Danae and Venus of Urbino by Titian (pictures $6 \mathrm{c}$ and $6 \mathrm{~d})$. Venus of Urbino, Olympia, and Maja are portrayed in domestic surroundings; both Venus of Urbino and Olympia have the same posture,

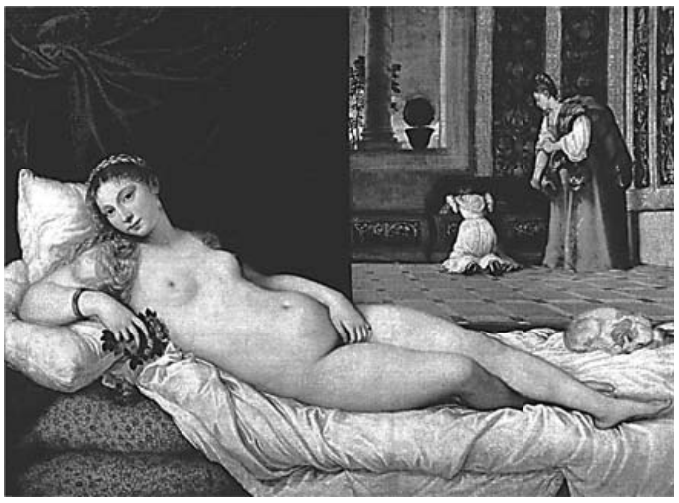

Picture 6d. Titian, Venus of Urbino 


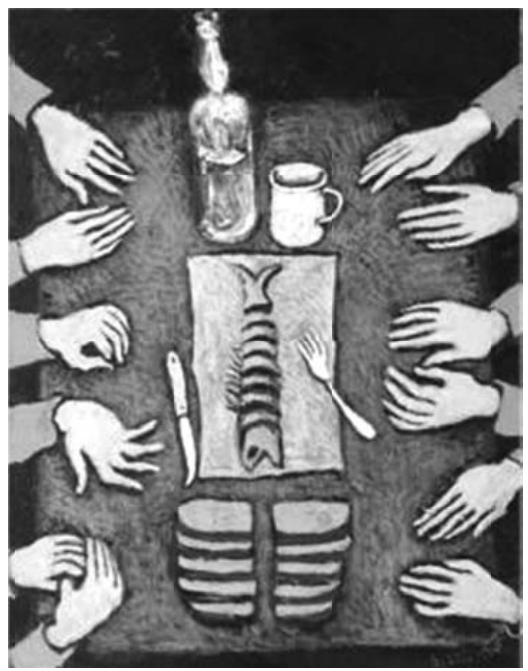

Picture 7. A. Eisenstadt. Feast in the Camp (Holiday in the Camp)

leaning on the right hand; both women have a bracelet on the right arm and glance at the viewer. Both Venus of Urbino and Olympia have a kitten or a puppy at their feet and a servant nearby. The glance of Olympia is as straight and open as that of Maja.

Such visual citations, like those in literature, introduce a new work in a familiar context. Specifically, meanings are transferred onto the canvas; the new is comprehended within the established. Related citations are found not only in paintings and literature but also in shows and concert performances (for example, performing the song "Live to Tell," Madonna appears crucified on a cross wearing a crown of thorns).

A special type of metonymy is synecdoche. Synecdoche (in Greek synecdoche is correlation) is defined by linguists (such as Rosenthal \& Telenkova, 1976; Reformatsky, 1999; Dibrova, Kosatkin, \& Scheboleva, 1997) as the transmission of meaning from one object to another, from one phenomenon to another, on the basis of the quantitative similarity between them. For example: Hey, beard! How do you get to Plyushkin's from here? (Nikolai Gogol), where "a man with a beard" and "beard" are correlated; And you, blue uniforms, and you, the people obedient to them (Mikhail Lermontov), referring to gendarmes. Synecdoche differs from 
metonymy in that both subjects have some unity, are related as a part of the whole, and do not exist independently (Zaretskaya, 2002).

Glazunov's The Last Leaf (Picture 4), portraying the legs of a man lying in bed, is an analogue of a synecdoche in visual terms. The legs refer to a whole image of the man.

A painting by A. Eisenstadt (Picture 7) portrays the hands of different people. A viewer can see here multiple meanings. On the one hand, these hands belong to different people with different characters (different gestures). On the other hand, these people are experiencing the extreme hardship of prison life. They have a different destiny, but they have the same fork, cup, bottle - and the same dark lot.

Exaggeration (hyperbole) is widely used in both art and literature, as is understatement or some other change of the dimension. In paintings, as Alexander Herzen wrote, "to sharpen angles and convexity thick paint is used" (Russkie pisateli o literaturnom trude, 1955, p. 38). Hyperbole (from the Greek hyperbole, exaggeration) is traditionally defined in linguistics as an "excessive exaggeration of certain properties of the depicted object or phenomenon" (Aksenova, 1974a, p. 59). This device is used to make the impression stronger. Mikhail Lomonosov gave the following definition: "Hyperbole is used when a positive notion makes a tension or passion stronger or weaker, e.g.: run quicker than a whirlwind; stars touching Atlas; temples made from the mountain" (Lomonosov, 1952 , p. 54). A visual analogue of hyperbole is also used to strengthen or weaken a "passion" - that is, to enhance the emotional impressions of an object or phenomenon.

In Russian literature hyperbole was widely used by Gogol, Mikhail Saltykov-Shchedrin, and especially Aleksey Tolstoy: My love, wide as the sea, cannot be accommodated by the coast of life. An example of hyperbole in painting is the image of a gigantic figure of a Bolshevik moving with a red banner across the city in the painting Bolshevik by Boris Kustodiev (Picture 8).

Very often methods of expressiveness are interconnected in the text as well as in the painting. Bolshevik depicts a Russian urban area, a metaphor for Russia during the Revolution (Sandomirsky, 2007). The giant figure of the Bolshevik moves along the street through a crowd of small people, inevitably crushing someone with each step; his next step can easily destroy the church. This is the way unbridled power and fear are portrayed. Without reference to critics' and biographers' opinions it is 


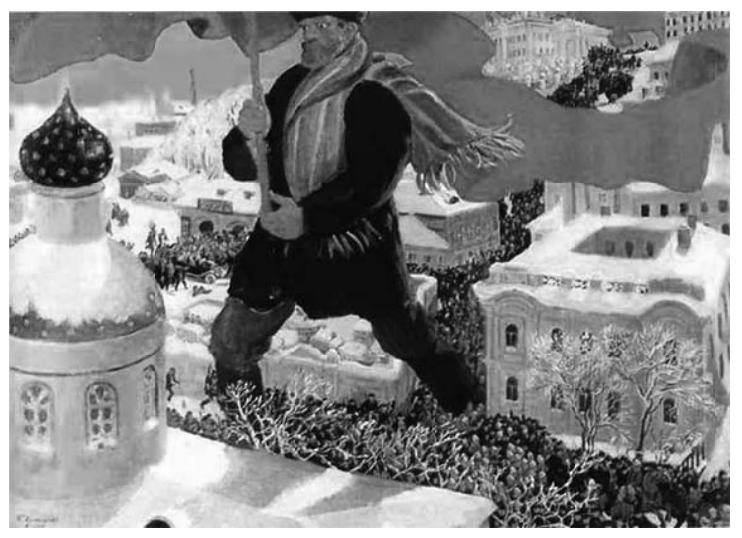

Picture 8. Boris Kustodiev, Bolshevik

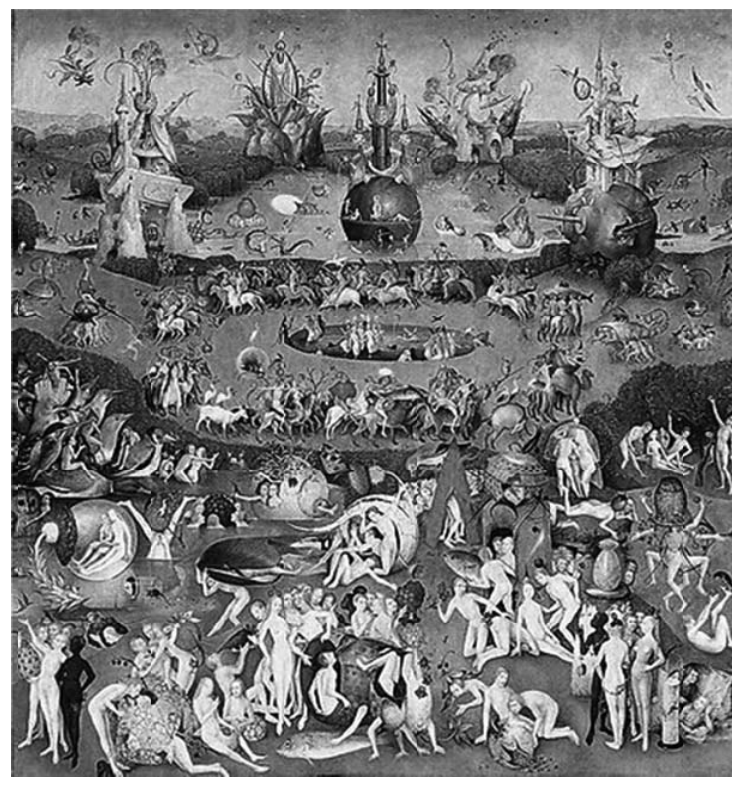

Picture 9. Hieronymus Bosch, Garden of Earthly Delights, a central part of the triptych 


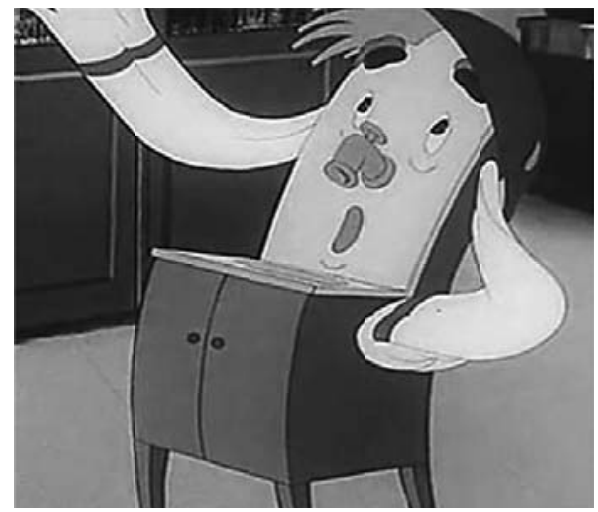

Picture 10. Prokofiev I. Moidodyr (Soyuzmultfilm, 1954, from a tale by Kornei Chukovsky)

difficult to appraise Kustodiev's work. How consciously did he depict the fear of the irresistible force of Bolshevism? Or was he full of ambivalent feelings of admiration for national power and unconscious fear of this force?

Litotes (from the Greek Litotes) is "a trope, the opposite of hyperbole. ...It is a phrase that contains an artistic understatement of the value, strength, semantics of a portrayed object or phenomenon" (Trofimov, 1974, p. 197), such as a small mouth that cannot chew more than two pieces (Gogol). Here, we can use as an example a painting by Hieronymus Bosch (Picture 9). The image of small human figures portrays the insignificance, restlessness, sinfulness of human life. Each figure is busy with its own business, pottering. The painting creates the impression of chaos, confusion; it is like a look from heaven at people's lives.

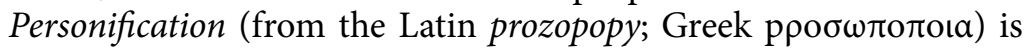
"an image of an inanimate or an abstract object possessing the qualities of living beings" (Aksenova, 1974d, p. 252). The inanimate objects can possess human qualities or they can possess the qualities of a mentioned concept: Bullets were singing, machine guns were beating, the wind was helping to lean palms on chests... more cheerlessly, stronger the wind rips the years from shoulders (Nikolai Aseev). The characters of the cartoon "Moidodyr" are visual analogues of personification (Picture 10). The 


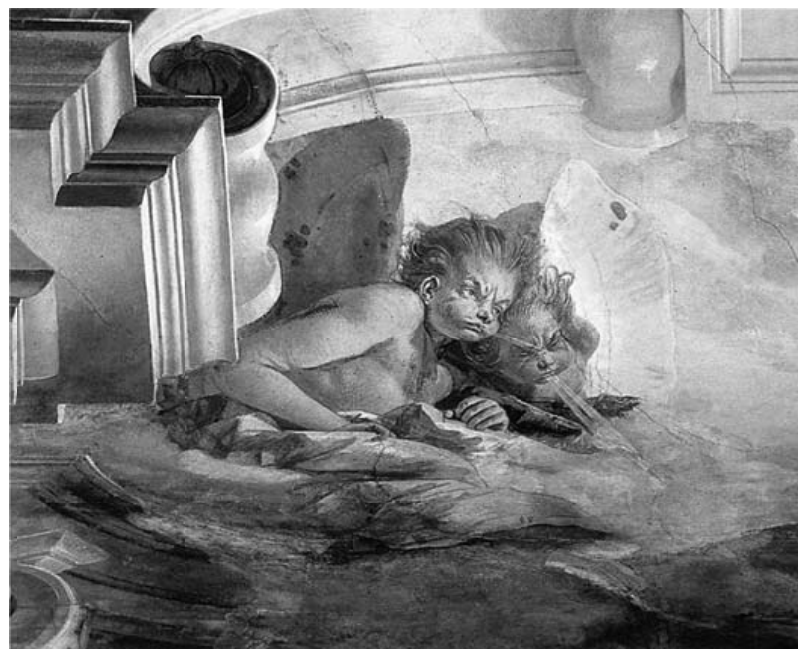

Picture 11. J. Battista Tiepolo, Wind (part of a mural)

main character of the cartoon (and the fairytale on which it is based) - a wash basin - possesses human qualities: it can speak, sigh, move, and see.

In addition, personification is always used in painting ancient gods and objects as human beings. In Picture 11 the wind has the appearance of a human being. When an object is personified, viewers get a chance to represent the object brighter and stronger in their minds.

Allegory (from Greek allos, different; agoreuo, say) is "a figurative portrayal of abstract concepts expressed through specific, living images: in fables and fairy tales cunningness is portrayed as a fox, greed as a wolf, insidiousness as a snake, etc." (Rosenthal \& Telenkova, 1976, p. 19). "Allegory is a specific depiction of an object or phenomenon of reality, replacing the abstract concept or idea. A green twig in the hands of a man has long been the allegorical depiction of peace, the hammer is an allegory of labor, etc." (Krupchanov, 1974a, p. 12.). "Allegory is a formallogical unit" (Losev, 1995, p. 152) - that is, an author using an allegory does not identify the allegorical image and depicted phenomenon: "a fabulist does not believe that animals speak like human beings" (Losev, 1995, p. 152). 
"The origin of most allegorical images can be found in the cultural traditions of tribes, people, and nations: they can be seen on the flags, emblems, badges and become sustainable. Many allegorical images date back to Greek and Roman mythology. Thus, the image of a blindfolded female having scales in her hands is the goddess Themis, an allegory of justice; the image of a snake and chalice is an allegory of Medicine" (Yartseva, 1990, p. 35). The goddess Psyche is often depicted as a butterfly or as being accompanied by one (Picture 12). Psyche, according to Greek mythology, is "mortal; [she] gained immortality, became a symbol of the soul, seeking her ideal" (Godefroy, 1992, pp. 83-84). Numerous examples of allegories can be found in medieval paintings.

Allegory as a way to enhance poetic expression is widely used in literature. It is based on the convergence of correlation effects and their essential aspects, qualities, or functions and refers to a group of metaphorical tropes (Riesel \& Schendels, 1975, p. 220). In a psychological sense, an allegory is an opportunity to experience some "inspiration,"

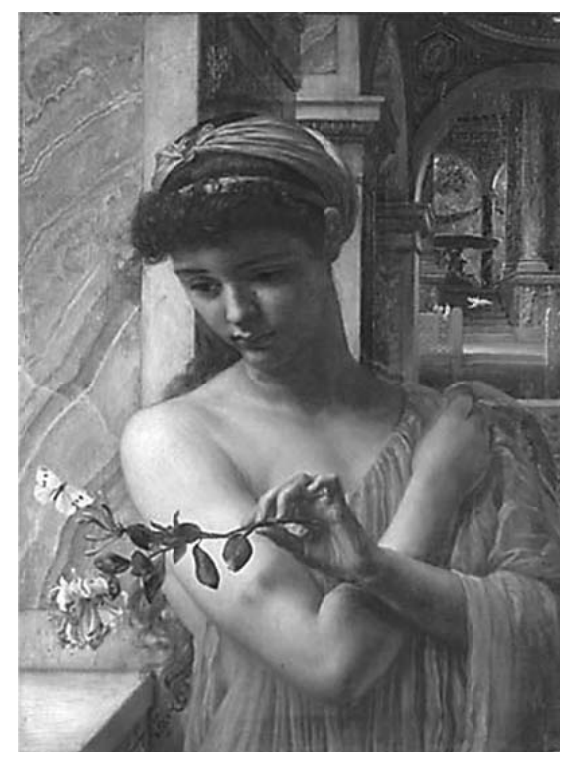

Picture 12. E. J. Poynter, Psyche in the Temple of Love 
the experience of discovery, when an idea is presented by means of unexpected tools. In a painting such "inspiration" is reserved and weak because the viewer is generally aware of the fact that the Greek gods are often portrayed as human beings.

Oxymoron (in Greek, oxymoron, acute stupidity) in the linguistic sense is a "combination of opposite definitions, concepts resulting in a new semantic quality" (Aksenova, 1974b, p. 252); it is a deliberate combination of contradictory notions: Look, she is being cheerfully sad. So smartly nude (Anna Akhmatova). An oxymoron is based on the unexpected combination of objects or concepts. "If [we] introduce logically incompatible things at the same time, the mechanism of consciousness begins to look for a way to bind them into a consistent unit. ... Consciousness is trying to get rid of ambiguities" (Allakhverdov, 2001, pp. 66, 72).

We can exemplify an oxymoron with a Soviet-era joke. For a competition on the anniversary of Lenin's birth, various industrial enterprises produced commemorative products: a furniture factory made a kingsize bed with the slogan "Lenin with us"; a bath and laundry enterprise made a bass with the motto "Following Lenin's path"; a clock plant produced a cuckoo clock - at twelve oclock sharp a tiny figure of Lenin in an armored car popped out; he was making a specific gesture and saying "coo-coo."

The combination of incompatible images in an oxymoron and the combination of two opposite parts in one, as in physics, creates the annihilation of particles and antiparticles, accompanied by the release of energy. The combination of the sacred (the image of the Great Leader) and the profane (the cuckoo clock) arouses a number of ambivalent emotions and reduces the initial energy of the emotionally significant object. Apparently, this is a fairly universal trope in carnival culture (Bakhtin, 1965) and in satire; it does not necessarily imply sacrilege. In deeply religious medieval Spain during carnival churchgoers might make a parody of bishops and make fun of high society using vulgar jokes, and in contemporary Catholic Spain one can easily buy toy monks and priests lifting a huge penis when a rear button is pressed. During Boris Yeltsin's presidency a TV show, The Dolls, used folk characters (like Vasily Ivanovich, Petka, and Anka the Machine-Gunner) to mock political leaders, thus making them recognized and popular with the audience. 


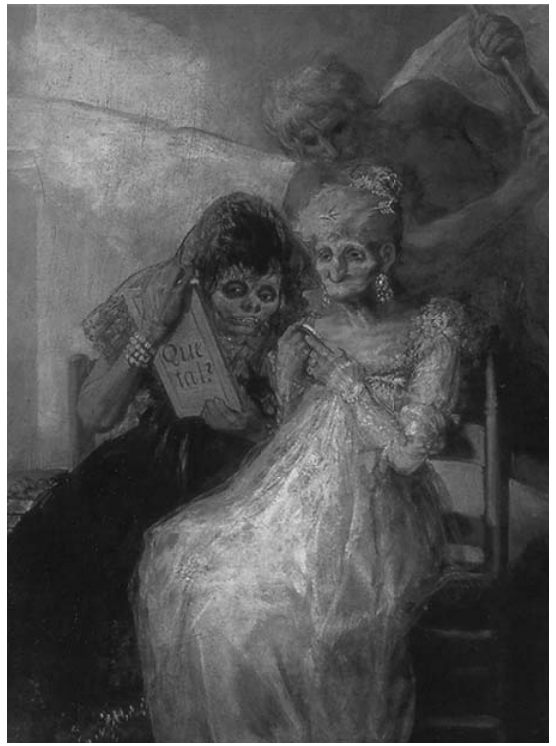

Picture 13. Francisco Goya, Old Women Looking in a Mirror

In the 1990s, when a government helicopter with senior government officials on board landed in some remote outback of Russia, the locals ran up to the helicopter shouting with a joy, "The Dolls have arrived!"

Another example of an oxymoron is Goya's painting Old Women Looking in a Mirror (or Time or Las Viejas - the painting has different names) (Picture 13).

The painting has satirical irony. In it an elderly woman wears bright makeup, makes a typical flirty gesture, and has a smiling facial expression. The clothing, the accessories, the hairstyle do not suit her face or her age. The grotesque exaggeration is evident to the viewer; such a portrait is interpreted on the one hand as deeply psychological and on the other hand as humorous.

Paraphrase (in Greek perifrasis, a descriptive expression) is another trope in linguistics; it "replaces the name of an object or person with their attributes" (Aksenova, 1974c, p. 267); it is "a stylistic device that gives the objects and phenomena an indirect and attributive description" (Yartseva, 1990, p. 371): young favorite of Thalia and Melpomene, 


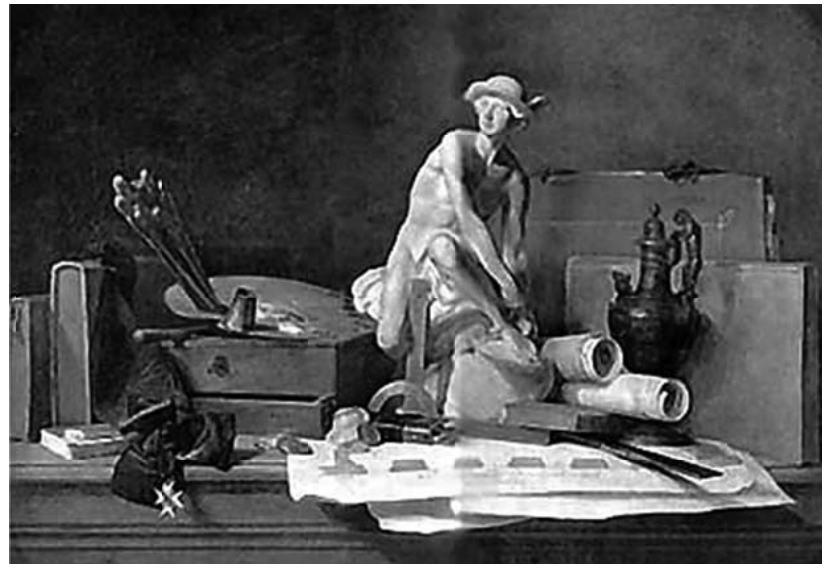

Picture 14. Jean-Baptiste-Siméon Chardin, The Attributes of the Arts and the Rewards Which Are Accorded Them

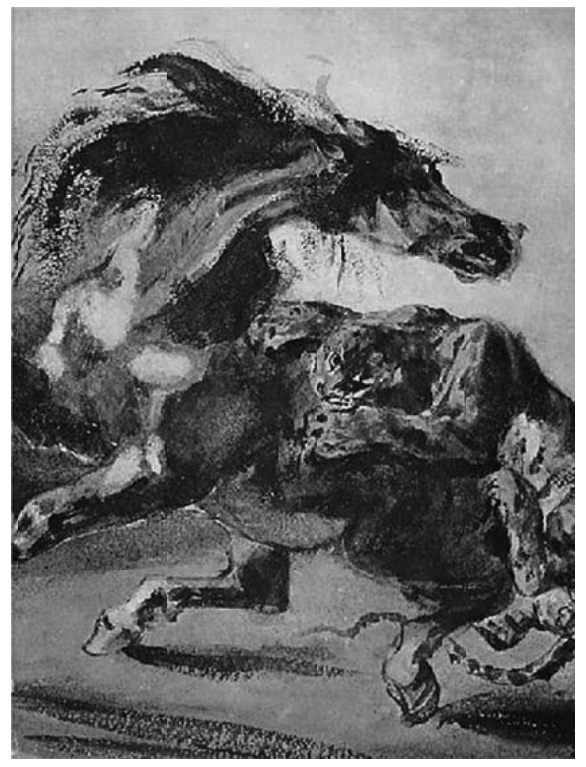

Picture 15. Eugène Delacroix, Tiger Attacking a Horse 

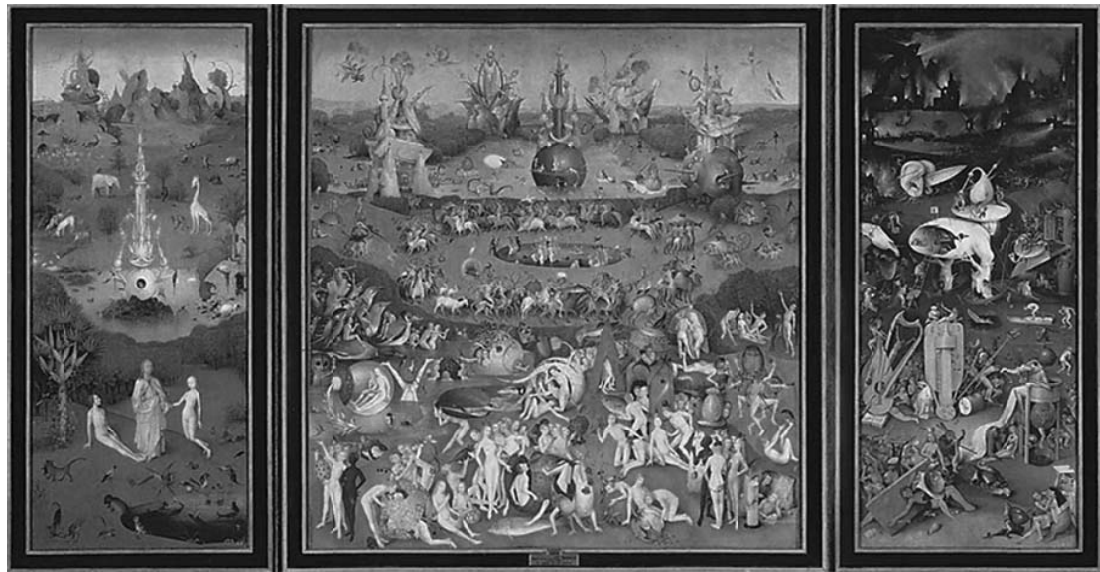

Picture 16a. Hieronymus Bosch, Garden of Earthly Delights

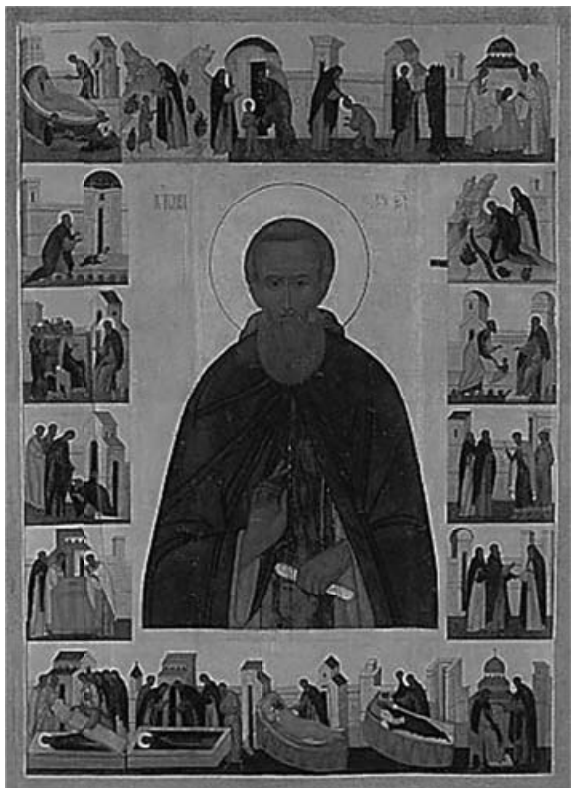

Picture 16b. Icon of St. Sergius and his hagiography 
generously gifted by Apollo (a young, talented actress) (Pushkin). A visual analogue of this trope requires the action and the attributes and the symbols of the action to be understood in the painting, although they are not portrayed in it. Other examples of a paraphrase are the illustrations on pages or covers of literature books that depict a pen, ink, paper lit by a candle. An example of a visual analogue of the trope is a well-known painting by Jean-Baptiste-Siméon Chardin, The Attributes of the Arts and the Rewards That Are Accorded Them (Picture 14). There is no artist in the painting, but all the objects refer to an artist who is painting a still life.

Antithesis (from the Greek antithesis, contrast) is "a contrast of concepts and phenomena" (Krupchanov, 1974b, p. 18). We can see an antithesis in Tiger Attacking a Horse (Picture 15), a painting by Eugène Delacroix. The coloring also creates a contrast: the two characters face each other, the hunter and the prey.

A triptych (for example, Picture 16a) or an icon with a hagiography (Picture 16b) consists of parts of a single idea that represent a type of story; such a "serial" is a device for making an image expressive. When viewers contemplate one picture of a triptych after another, they can trace the change in the plot. A triptych or a hagiography is a kind of a film that shows a story through plot changes.

Some of the stylistic devices used in painting have no analogues in literature - for example, using contradictions in the logic of objects; compare the image of the violin in different projections by Pablo Picasso (Picture 17). The portrayal of an object in different projections is a technique that allows one to go beyond stereotypes, to have a different image to compare and contrast. Such an image gives new meaning to the object.

In painting, unlike in literature, an observer inevitably has a perspective; it is usually similar to the artist's. In a literary text the narrator can have several possible perspectives; the narrator can be either an author or a protagonist and also can change perspective in the course of the narration. For example, the main character becomes an insect and begins to see the world differently in The Metamorphosis (1915) by Franz Kafka and in the short story "The Granton Star Cause" (1994) by Irvine Welsh. In a literary text, the change of perspective takes a long time, whereas in a painting it is simultaneous. So, an image of a mirror 


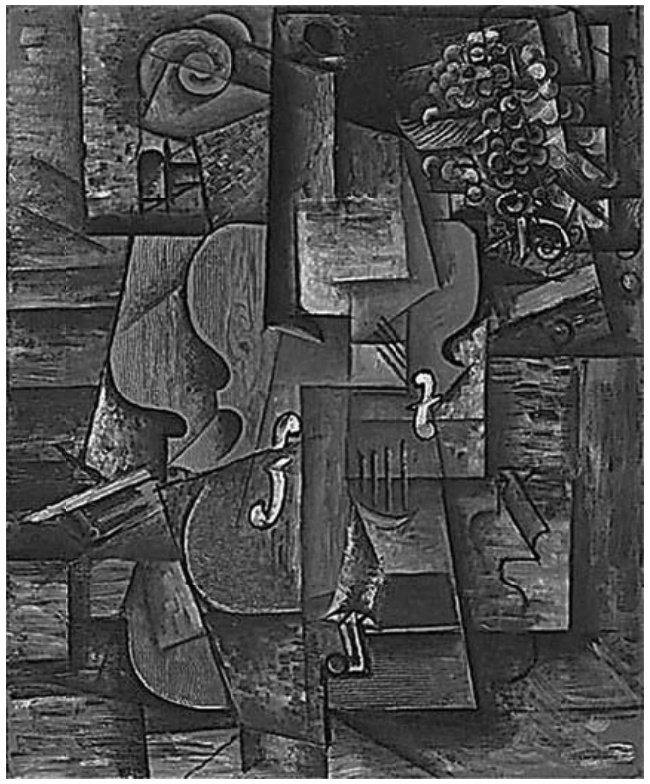

Picture 17. Pablo Picasso, Violin and Grapes

provides an observer with multiple possible perspectives simultaneously; see, for example, the painting Laughing Couple (Joking Couple) by Hans von Aachen (Picture 18). The man, holding a mirror, is gazing with passion at a young woman. The woman is admiring herself in the mirror. The painting (like a polyphonic novel by Bakhtin) gives an observer multiple perspectives: that of the gazing man, that of the young woman; the viewer's perspective apparently agrees with that of the artist.

An image of a mirror is a typical method of visual semantics; it is like a Russian doll: a portrayal of space inside space. A story is always given to the audience from a certain perspective: "The objects... depicted in the picture can be visible to us only from a particular side and distance from the side, which [are]... chosen and captured by the artist in his paintings" (Ingarden, 1962, p. 280); using a mirror an artist can portray additional perspectives. In paintings such techniques make it possible to consider the object from different perspectives and to open 


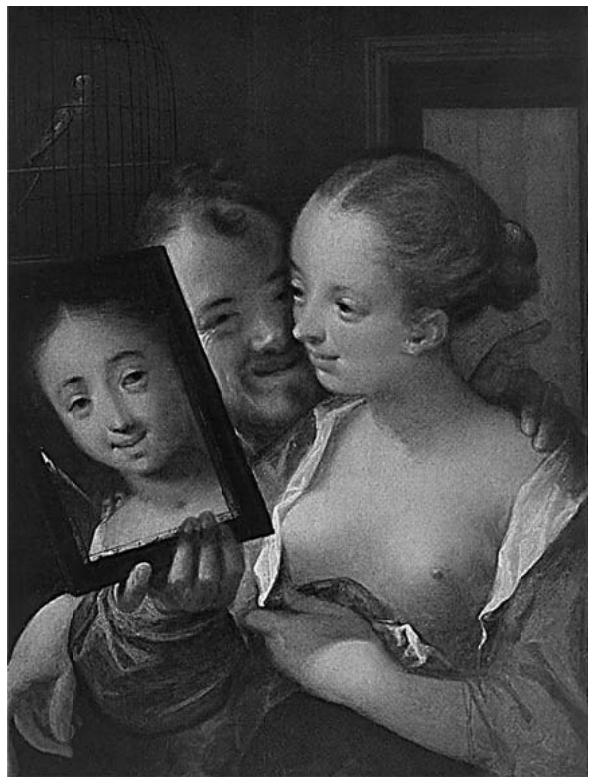

Picture 18. Hans von Aachen, Laughing Couple (Joking Couple)

up additional dimensions in the picture. Here we have symbolism: the ability to see something implicit, to understand the secret. This device introduces a viewer to something implicit. The more perspectives in a work of art (in painting as well as in literature), the more multidimensional the work is. In painting, the viewer's perspective is more essential than it is in literature. A similar method in literature is a hypertext, which is a text within a text.

The painting Slave Market with the Invisible Bust of Voltaire by Dali (Picture 19) exemplifies the psychological method of background change, in which the viewer alternately sees two nuns (another interpretation is "ladies wearing Dutch dresses") or a bust of Voltaire (by Jean-Antoine Houdon).

In addition to the psychological method of background change, which creates various semantic meanings (gestalts), perception is also influenced by eye movements over the painting. Focusing attention on one element of the painting after another creates a semantic contrast or, 
on the contrary, stresses their semantic similarity. This characteristic of human perception is used in still lifes, landscapes, and film.

Analysis of a picture by an unknown Korean artist (Picture 20) exemplifying figurative opposition reveals a semantic contrast: stable and permanent (houses on a rocky stronghold) vs. ever-changing, soft, and rolling (mountain stream); but there is also another contrast: man-made, vulnerable to decay and breakup (the dwellings) vs. natural, ever-changing, but eternal (mountain stream).

Special methods of filmmaking, such as editing and close shots, should be mentioned. A series of film shots makes the content comprehensible, affects the emotional state of the viewer (the Kuleshov effect), and ultimately makes comprehension easy. Film structure is more essential and more expressive than "one point" structure (Eisenstein, 1938).

A painting (an image) is like a text to be read. A successfully used trope in a text is a source of its figurativeness and gives it new meaning. Tropes can also change the perception of the text's content by encourag-

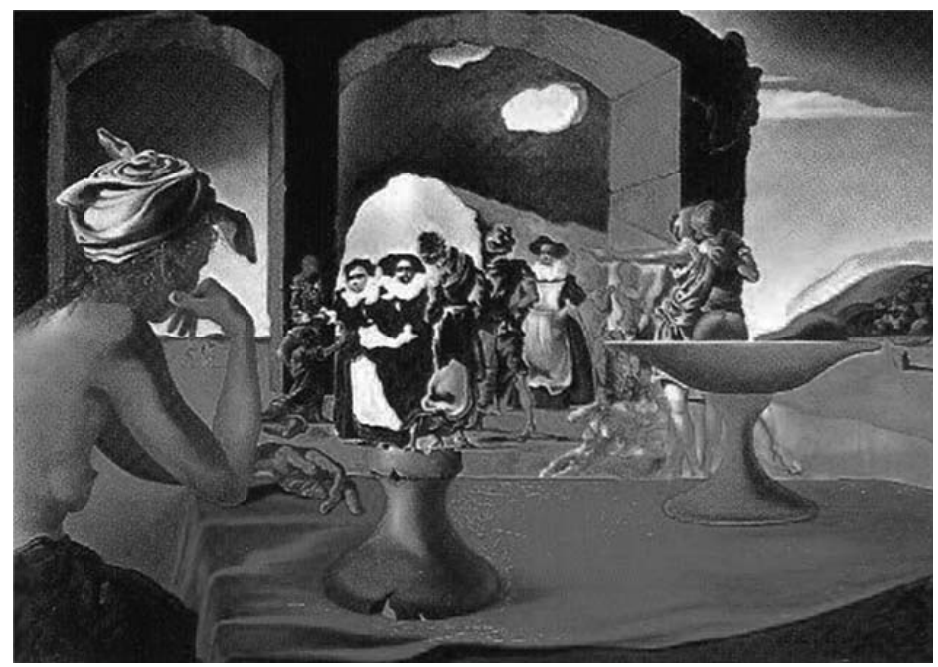

Picture 19. Salvador Dali, Slave Market with the Invisible Bust of Voltaire 


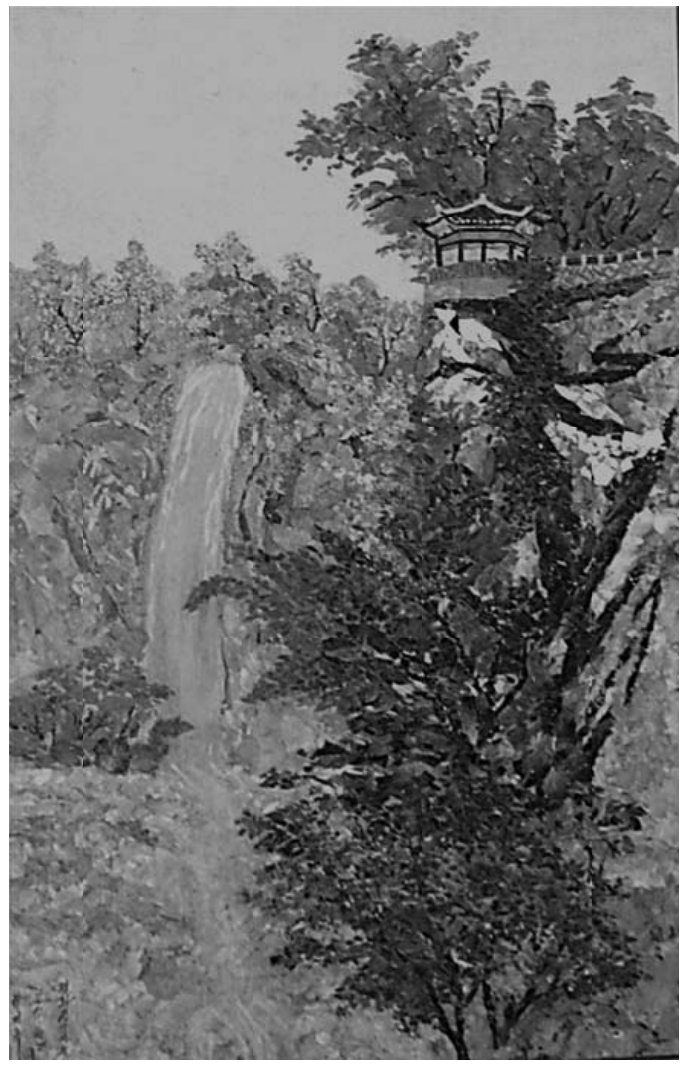

Picture 20. Painting by an unknown Korean artist

ing the use of imagination and guesses or by developing the plot, whenever possible, on the basis of comparison or metaphor (or other tropes). Each method of expression somehow modifies the image. Such methods and techniques encourage viewers to use their imaginations and to alter their emotional states (the psychological method). Using direct and inverse perspective, the method of the mirror, and background change; altering viewers' perspectives; changing focus; editing; and so forth are obviously widely examined in the semiotics of art. 


\section{Conclusion}

When the elder of the coauthors of this article was a student, the renowned scientist Alexander Luria used to give lectures on psychology; he clearly distinguished the cognitive unit, which includes the work of memory, mental processes, and speech, from the emotional and energy unit of the human psyche, which includes needs, emotions, and motives. For Luria this contrast was not absolute; so he quoted L. Vygotsky and S. Rubinstein sympathetically on the "connection of emotional and cognitive processes" and the "unity of affect and intelligence." Nevertheless, nowadays the connection of these mental spheres (perceptional and emotional) remains ill-researched, and issues about will, action, language, creativity, and emotional state are very rarely researched in combination.

A detailed article by Schultz and Lyubimova analyzes W. Humboldt's idea of the internal energy of language and its involvement in action. "Expressing the will, language becomes action. The origin of language, according to [Humboldt], is in people's strength and will. It is prospective action, which has verbal form and expresses the past will, [and] structures and defines reality. This thesis by $\mathrm{M}$. Foucault... goes back to Humboldt (Schultz \& Lyubimova, 2008, p. 45).

The original interpretation of Humboldt's ideas led to the "philosophy of the name," a distinctive movement in Russian philosophy in the 1910 s and 1920s, developed in the works of P. Florensky, S. Bulgakov, and A. Losev. According to Losev, the inner core of a name is formed by a certain power or energy. A word gets energized through its inherence in different positions in various levels of life. Schultz and Lyubimova cite Cassirer: "The ability to comprehend names means to think and act magically" (2008, p. 42). "A magical word does not describe objects and the relations between objects; it aims to produce actions and change natural phenomena, and the magical function of a word dominates the semantic function" (Cassirer). The worldview of the German Romanticists, the French symbolists, the above-mentioned Russian Orthodox existentialist philosophers of the magic of words, of the symbolic image as a reflection of the spiritual, is expressed in the Russian poetry of the Symbolists and Acmeists of the Silver Age (Blok, Nikolay Gumilev, Akhmatova). 
In that day when the world is new

When God bowed his face,

The Sun was stopped by a word,

The word of destroying the city.

And the eagle was not flapping its wings,

The stars huddled to the Moon in horror

Like a pink flame

The word floated in the sky.

We have not forgotten the sowed

Only the word among the earthly troubles,

And in the Gospel of John

Was said, the word is God. (Gumilev, 1990, p. 201)

Understanding the text and figurative art, carrying internal energy and changing emotional states not only of the creator of a work of art but also of the spectator, or, even more broadly, transforming the energy of an area and a society inspired us to write this text. "Art... has such high artistic images, which aim to be not only a self-sufficient object of love for pleasure [and]... instruments of human orientation in the vast sea of reality, but also an instrument for its creative remake" (Losev, 1995; italics added) .

Having analyzed the problems of metaphor and similar tropes, we have tried in this article to extend this philological perspective to a broader semiotic area, including visual art; we have provided in the text numerous illustrations to show the application of these tropes to artistic intuition from the perspective of the reader and the viewer. There is nothing new in this world; deep thoughts and observations on this subject have already been provided by Arutyunova (1990), Ivanov (1973, 1981), Lakoff \& Johnson (1987), Lotman (1973; Ju.M. Lotman i tartuskomoskovskaja semioticheskaja shkola, 1994). Our specific approach to this theme is the following: being professional psychologists, we analyzed tropes, primarily through a mental operation that constructs a psychological image, introducing it in a holistic context (discourse), defining its emotional attitude, generating and stressing its meanings.

For example, psychological analysis of the communicative impact of neurolinguistic programming (NLP) (Bandler \& Grinder, 1995) has 
revealed behavioral methods ranging from Pavlov's conditioned reflex to light hypnotherapy and works by the hypnotherapist Milton Erickson. One of the major works of Bandler and Grinder is reasonably called The Structure of Magic (1975a, 1975b), as in this approach the verbal text, having aspects mentioned in the quote from Cassirer above, is regarded as a magical act.

Unlike a psychoanalyst, who serves as an interpreter of messages of the unconscious (dreams, slips of the tongue, inappropriate actions, and so forth) and thereby completely overhauls the repressed past in the patient's memory, an NLP practitioner can (and even should) be interested in the content of the traumatic experiences of the patient. The patient is asked to make in his or her mind (but not to reveal) a picture of the stressful situation arousing negative emotions, to observe the situation, and to become a spectator. The patient may set the situation closer or remove it; may make it duller or brighter; may change the sharpness, and so forth. In any case, the patient switches from being a sufferer, who experienced the trauma, to being an observer and a researcher, realizing the situation to be just another life experience. It is not only self-reflection can change a personal trauma into a general case of human experience. The use of mental operations changes emotional and mental states (for example, from an emotionally depressed state into a state of spiritual peace or even a creative upsurge, when self-reflection needs a keen dialogue).

In literature the method of "detachment" is widely used; for example, in the novels of Albert Camus, the events of a character's life are depicted as if from the outside and are completely detached from emotions. In Camus's novel A Stranger the main character, describing his upcoming death, which is the penalty for a murder he committed, switches to emotionally neutral, "behavioral" language: "The French government should cut off my head," etc. One of Gogol's stories, about receiving a long-awaited official award, is narrated from a dog's perspective; the dog has no understanding of the whole social order and evaluates the award as being edible or not edible.

In Kafka's novel The Metamorphosis, the narrator is a predatory insect, which one of the characters turned into. If the method of "detachment" allows release of the emotional tension in a perceived situation by depersonalizing it, then perception from a different point of view - from the perspective of a foreign-language speaker, a native of a foreign cul- 
ture, an alien (as in Solaris by S. Lem) - allows one to go beyond the stereotyped categorization of the situation, of one's own self, of the world. Such detachment allows one not only to see in a different way but to construct other worlds of existence; according to Castaneda, it gives "other points for unity."

Analysis of poetry and painting through the use of mental operations and ways of working with meanings (particularly as expressed by tropes) requires an extended conceptual thesaurus of philological and semiotic terms and the introduction of definitions for such concepts as energy, representation, empathy and synchronicity, modified forms of consciousness, the magic of a word and the magic of an image, thinking - action, idea - image, "objectifying" of imagination, construction of artistic possible worlds. According to Gostev $(1998$, p. 6), "Most people do not realize that their fate depends on the content of their imagination; imagination can fortunately or unfortunately get realized spontaneously." The point is that images create a unique "matrix" that attracts human psychic energy; it is filled with "a living material." The result is the creation of a program to realize the wanted or the unwanted.

This new field of study of the communicative impact of energy, of energy and information, arises at the intersection of art, poetry, the humanities, philosophy, semiotics, linguistics, psychology, communication theory, and the natural sciences (physics, information theory, proxemics, synergetics); it is awaiting its pioneers and researchers.

\section{Acknowledgement}

This study was supported by grant № 11-06-00242-a from the RHSE.

\section{References}

Aksenova, E. (1974a). Giperbola [Hyperbole]. In Slovar' literaturovedcheskih terminov [Dictionary of literary terms]. Moscow: Prosveshchenie.

Aksenova, E. (1974b). Oksjumoron [Oxymoron]. In Slovar' literaturovedcheskih terminov [Dictionary of literary terms]. Moscow: Prosveshchenie.

Aksenova, E. (1974c). Perifraz [Paraphrase]. In Slovar' literaturovedcheskih terminov [Dictionary of literary terms]. Moscow: Prosveshchenie. 
Aksenova, E. (1974d). Olicetvorenie [Personification]. In Slovar' literaturovedcheskih terminov [Dictionary of literary terms]. Moscow: Prosveshchenie.

Alexandrov, D.N. (1999). Ritorika: Ucheb. posobie dlja vuzov [Rhetoric: A manual for high schools]. Moscow: Unity-Dana.

Allakhverdov, V.M. (2001). Psihologija iskusstva. Jesse o tajne jemocional'nogo vozdejstvija hudozhestvennyh proizvedenij [Psychology of art: Essays on mystery of emotional impact on artworks]. St. Petersburg: DNK.

Arabov, Y.N. (2003). Kinematograf i teorija vosprijatija [Filming and theory of perception]. Moscow: VGIK.

Arnheim, R. (1973). Vizual'noe myshlenie [Visual thinking]. In Zritel'nye obra$z y$ : fenomenologija $i$ jeksperiment [Visualization: Phenomenology and experiment] (Ch. 2, 3). Dushanbe.

Arnheim, R. (1974). Iskusstvo i vizual'noe vosprijatie [Art and visual perception]. Moscow: Progress.

Arnheim, R. (1994). Novye ocherki po psihologii iskusstva [New essays on psychology of art]. Moscow: Prometej.

Arnheim, R. (2004). Visual thinking. Retrieved from http://www.philosophy.ru/ library/katr/arnheim1.html

Arutyunova, N. D. (1990). Metafora i diskurs [Metaphor and discourse]. In Teorija metafory [Theory of metaphor] (pp. 5-32). Moscow: Progress.

Arutyunova, N.D. (1979). Jazykovye metafory [Linguistic metaphors]. In Lingvistika i pojetika [Linguistics and poetics] (pp. 120-139). Moscow: Nauka.

Bakhtin, M.M.(1965). Tvorchestvo Fransua Rable inarodnaja kul'turaSrednevekov'ja $i$ Renessansa [Creation of François Rabelais and folk culture of the Middle Ages and Renaissance]. Moscow: Hudozhestvennaja literatura.

Bakhtin, M.M. (1986). K metodologii gumanitarnyh nauk [About the methodology of humanities]. In M.M. Bakhtin, Jestetika slovesnogo tvorchestva [Aesthetics of Verbal Creativity] (pp. 381-393). Moscow: Iskusstvo.

Bandler, R., \& Grinder, J. (1975a). The Structure of Magic I: A Book about Language and Therapy. Palo Alto, CA: Science \& Behavior Books.

Bandler, R., \& Grinder, J. (1975b). The Structure of Magic II: A Book about Communication and Change. Palo Alto, CA: Science \& Behavior Books.

Bandler, R., \& Grinder, J. (1995). Pefrejming: orientacija lichnosti s pomoshch'ju rechevyh strategij [Reframing: Making individual through verbal strategies]. Voronezh: NPO Modek.

Bassin, F.V., Prangishvili, A.S., \& Sherozia, A.E. (1978). O projavlenii aktivnosti bessoznatel'nogo $\mathrm{v}$ hudozhestvennom tvorchestve [The activity of the unconscious in artistic creation]. Voprosy filosofii [Philosophy Issues], 2, 57-69.

Carroll, N. (1996). A note on film metaphor. Journal of Pragmatics, 26(6), 809-822. 
Chernets, L.V. (2000a). “...Plylo oblako, pohozhee na rojal” (O sravnenii) [“The cloud was floating like a piano” (On comparison)]. Russkaja slovesnost' [Russian Literature], 2, 75-79.

Chernets, L.V. (2000b). "Nochevala tuchka zolotaja..." (o metafore) ["Sleeping golden cloud..." (On metaphor)]. Russkaja slovesnost' [Russian Literature], 6, 73-78.

Dibrova, E.I., Kasatkin, L.L., \& Scheboleva, I.I. (1997). Sovremennyj russkij jazyk. Teorija. Analiz jazykovyh edinic. Ch.1 [Modern Russian language. Theory. The Analysis of Linguistic Units. Part I]. Rostov-na-Donu: Phenix.

Eisenshtein, S.M. (1938). Montazh [Montage]. Moscow: VGIK.

Forceville, C. (1994). Pictorial metaphor in advertisements. Metaphor and Symbolic Activity. 9(1), 1-29.

Forceville, C. (1995). IBM is a tuning fork: Degrees of freedom in the interpretation of pictorial metaphors. Poetics, 23, 189-218.

Forceville, C. (1996). Pictorial Metaphor in Advertising. London: Routledge.

Gibson, J. (1998). Jekologicheskij podhod k zritel'nomu vosprijatiju [An Ecological Approach to Visual Perception]. Moscow: Progress.

Godefroy, J. (1992). Chto takoe psihologija [What is psychology] (Vol. 1). Moscow: Mir.

Gostev, A.A. (1998). Doroga iz Zazerkal'ja: psihologija razvitija obraznoj sfery. Trening tvorcheskogo voobrazhenija [Beyond the reality: Psychology of human creativity]. Moscow: Institue of Psychology of Russian Academy of Sciences.

Gumilev, N. (1990). Dramaticheskie proizvedenija. Perevody. Stat'i [Poems. Letters of Russian Poetry]. Moscow: Hudozhestvennaja literatura.

Ingarden, R. (1962). Issledovanija po jestetike [Studies on Aesthetics]. Moscow: Inistrannaya literatura.

Ivanov, V.V. (1973). Fil'm v fil'me [Film in the film]. In Trudy po znakovym. sistemam [Sign Systems Studies], 6. Tartu. (Uchenye zapiski Tartuskogo gosudarstvennogo universiteta [Scientific Issues of Tartu State University]).

Ivanov, V.V. (1981). Fil'm v fil'me [Film in the film]. In Trudy po znakovym.sistemam [Sign Systems Studies], 14. Tartu. (Uchenye zapiski Tartuskogo gosudarstvennogo universiteta [Scientific Issues of Tartu State University]).

Ivanov, V.V. (1998). Nechet i chet [Even and odd]. In V.V. Ivanov, Izbrannye trudy po semiotike $i$ istorii kul'tury [Selected works on semiotics and cultural history] (vol. 1, pp. 379-602). Moscow: Yazyki russkoj kultury.

Ju.M. Lotman i tartusko-moskovskaja semioticheskaja shkola [Ju.M. Lotman and Tartu-Moscow Semiotic School]. (1994). Moscow: Gnozis.

Khachaturov, S. (2002). Bumazhnye angely [Paper angels]. Vremja novostej [News Time], 90 (May 23). URL: http://www.vremya.ru/2002/90/10/23313.html. Retrieved from http://www.vremya.ru/print/23313.html 
Krupchanov, L. (1974a). Allegorija [Allegory]. In Slovar' literaturovedcheskih terminov [Dictionary of literary terms]. Moscow: Prosveshchenie.

Krupchanov, L. (1974b). Antiteza [Antithesis]. In Slovar' literaturovedcheskih terminov [Dictionary of literary terms]. Moscow: Prosveshchenie.

Lakoff, G., \& Johnson, M. (1987). Metafory, kotorymi my zhivem [Metaphors we live by]. In Jazyk i modelirovanie social'nogo vzaimodejstvija [Handbook. Language and Social Interaction Simulation (pp. 126-170). Moscow: Progress.

Leont'ev, A.A. (1997). Osnovy psiholingvistiki [Fundamentals of psycholinguistics]. Moscow: Smysl.

Lomonosov, M.V. (1952). Polnoe sobranie sochinenij [Collection of Works] (vol. 7). Moscow; Leningrad: AN USSR.

Losev, A.F. (1982). Problema variativnogo funkcionirovanija zhivopisnoj obraznosti v hudozhestvennoj literature [The issue of the variable operation of artistic imagery in fiction]. In Literatura $i$ zhivopis' [Literature and painting] (pp. 31-65). Leningrad: Nauka.

Losev, A.F. (1991). Filosofija. Mifologija. Kul'tura [Philosophy. Mythology. Culture]. Moscow: Politizdat.

Losev, A.F. (1995). Problema simvola i realisticheskoe iskusstvo [Symbol issues and realistic art]. Moscow: Iskusstvo.

Lotman, Ju.M. (1973). Semiotika kino i problemy kinojestetiki [Semiotics in cinematography and issues of film aesthetics]. Tallinn, Estonia: Eesti Raamat.

Luria, A.R. (2004). Lekcii po obshchej psihologii [Lectures on general psychology]. St. Petersburg: Piter.

Melchuk, I.A. (1974). Opyt teorii lingvisticheskih modelej "Smysl-Tekst": semantika, sintaksis [Toward a Theory of Linguistic Models of the Type "Meaning-Text": semantics, syntax]. Moscow: Nauka.

Mol', A. (1966). Teorija informacii i jesteticheskoe vosprijatie [Information theory and aesthetic perception]. Moscow: Mir.

Naer, V.L. (1976). Konspekt lekcij po stilistike anglijskogo jazyka [Lectures on the stylistics of the English language]. Moscow: MGPIIJa.

Petrenko, V.F. (1976). K voprosu o semanticheskom analize chuvstvennogo obraza [On the semantic analysis of the sensory perception]. In A.N. Leont'ev (Ed.), Vosprijatie $i$ dejatel'nost' [Perception and activity] (pp. 268-292). Moscow: Moscow State University.

Petrenko, V.F. (1988). Psihosemantika soznanija [Psychosemantics of consciousness]. Moscow: Moscow State University.

Petrenko, V.F. (1997). Osnovy psihosemantiki [Basics of psychosemantics]. Moscow: Moscow State University. 
Petrenko, V.F. (1998). Psychosemantic Analysis of a Painter's Self-Awareness by Yis Self-Portraits. XV Congress of the International Association of Empirical esthetics. Rome.

Petrenko, V.F. (2005). Osnovy psihosemantiki (2-e izd., dop). [Basics of psychosemantics (2nd ed., modified.)]. St. Petersburg: Piter.

Petrenko, V.F., \& Korotchenko, E.A. (2008). Pejzazh dushi. Psihosemanticheskoe issledovanie vosprijatija zhivopisi [Landscapes of the soul. Psychosemantic study of perception of paintings]. Jeksperimental'naja psihologija [Experimental Psychology], 1, 84-101.

Potebnya, A.A. (1990). Teoreticheskaja pojetika [Theoretical poetics]. Moscow: Vysshaja shkola.

Rappoport, S.H. (1978). Ot hudozhnika k zritelju: Kak postroeno i kak funkcioniruet proizvedenie iskusstva [From artist to viewer: The construction and function of artworks]. Moscow: Sovetsky Khudozhnik.

Refaie, E. (2003). Understanding visual metaphor: The example of newspaper cartoons. Visual Communication, 2(1), 75-95.

Reformatsky, A.A. (1999). Vvedenie v jazykovedenie [Introduction to linguistics]. Moscow: Aspect Press.

Riesel, E., \& Schendels, E. (1975). Deutsche stilistik. Moscow: Verlag Hochschule.

Rosenthal, D.E., \& Telenkova, M.A. (1976). Slovar'-spravochnik lingvisticheskih terminov [Dictionary of linguistic terms] (2nd ed.). Moscow: Prosveshchenie.

Russkie pisateli o literaturnom trude (XVIII-XX vv.) [Russian writers on literature (XVIII-XX centuries)] (1955) (vol. 2). Leningrad: Sovetskij pisatel'.

Ruuber, G. (1985). O zakonomernostjah hudozhestvennogo vizual'nogo vosprijatija [On the principles of visual art perception]. Tallinn: Valgus.

Sandomirsky, C. (2007, January). Iskusstvo prochtenija zhivopisi [The art of reading painting]. Russian Globe Online Journal, 1. Retrieved from http://www.russianglobe.com/N59/Sandomirsky.Kustodiev.Bolshevik.htm

Schultz, V.L., \& Lyubimova, T.M. (2008). Jazyk kak metareal'nost' i prognosticheskaja struktura [Language as a material thing and a prognostic structure]. Voprosy filosofii [Philosophy Issues], 7, 38-50.

Shklovsky, V.B. (1983). Izbrannoe [Selected works] (vol. 1). Moscow: Hudozhestvennaja literatura.

Timofeev, A.I., \& Turaev, S.V. (1978). Kratkij slovar' literaturovedcheskih terminov [Small dictionary of literary terms]. Moscow: Prosveshchenie.

Trofimov, V.I. (1974). Litota [Litotes]. In Slovar' literaturovedcheskih terminov [Dictionary of literary terms]. Moscow: Prosveshchenie.

Ushakova, T.N. (2006). Psiholingvistika [Psycholinguistics]. Moscow: PUR SE. 
Yarbus, A.L. (1965). Rol' dvizhenij glaz v processe zrenija [The role of eye movements in vision]. Moscow: Nauka.

Yartseva, V.N. (Ed.). (1990). Lingvisticheskij jenciklopedicheskij slovar' [Linguistic encyclopedic dictionary]. Moscow: Sovetskaja Jenciklopedija.

Zaretskaya, E.N. (2002). Ritorika: teorija i praktika rechevoj kommunikacii [Rhetoric. Theory and Speech Communication Practice]. Moscow: Delo.

Zinchenko, V.P. (2001). Myshlenie i jazyk [Mind and language]. Dubna.

Zinchenko, V.P. (2005). Zagadka tvorcheskogo ponimanija (K 100-letiju D.B. Jel'konina) [Mystery of creative understanding (for 100-year anniversary of D.B. Elkonin)]. Voprosy psihologii [Psychology Issues], 1, 22-34.

Znakov, V.V. (2005). Psihologija ponimanija [Psychology of understanding]. Moscow: Institut psihologii RAN. 